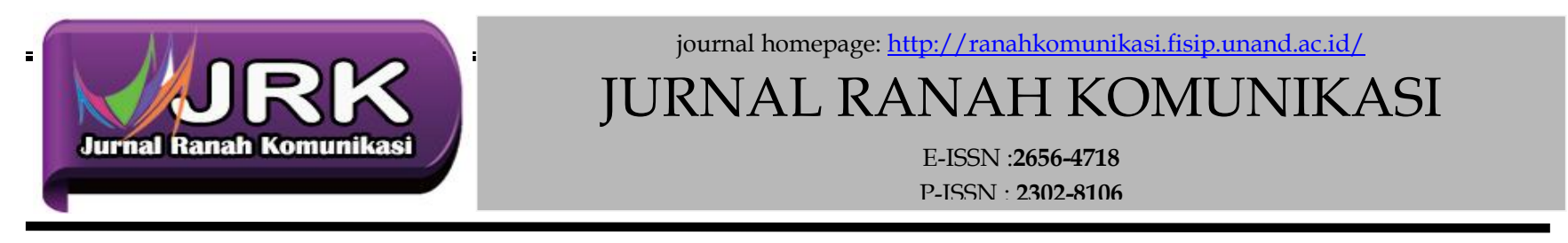

\title{
PENGARUH GLASS CEILING TERHADAP PENGEMBANGAN KARIR WANITA DI DUNIA PENDIDIKAN
}

\author{
Tessa Shasrini ${ }^{1)}$, Al Sukri ${ }^{2}$ \\ 1) Jurusan Ilmu Komunikasi, Universitas Islam Riau, E-mail: tessashasrini@comm.uir.ac.id \\ 2) Jurusan Ilmu Komunikasi, Universitas Islam Riau, E-mail: alsukri_jn @ comm.uir.ac.id
}

\section{ARTICLE INFORMATION}

KEYWORDS:

Glass Ceiling, Pengembangan Karir, Wanita, Pendidikan

\section{CORRESPONDENCE}

Phone:

E-mail:

\section{A B S T R A C T}

This research was conducted with a focus on the problem of Women's Career Development Glass. The total study is a conceptual framework structure built using quantitative research methods. Research is carried out with the aim of getting a goal. Namely "To Know the Effect of Glass Ceiling on Teacherfocused Women's Career Development. "At the same time, a hypothesis was developed to find out whether individual factors, family factors, organizational and cultural factors significantly influence Women's Career Development Factors. Only this study has been completed with a comprehensive empirical survey using a self-administered questionnaire and the sample consists of. of 110 female teachers. To present and analyze both descriptive and statistical data used. The findings reveal the Glass Ceiling and career development of women have a positive relationship, and also show that individual factors, organizational factors and cultural factors have a significant effect on development. Career of Women Whereas Family Factors have no effect on the Glass Ceiling The results of this study confirm that there is no effect on the effect of the glass ceiling. Taking all these facts into account, there is a better recommendation to be made in this study. In the end, the most important suggestion. Requirements for future research and study limitations have been outlined in this study.

\section{INTRODUCTION}

Dalam Instruksi Presiden Nomor 9 Tahun 2000 tentang PUG dalam Pembangunan Nasional memberikan perintah kepada semua lembaga pemerintahan untuk dapat melakukan pembangunan dengan berperspektif gender sesuai dengan bidang dan kewenangannya masing-masing. Dalam bidang pendidikan, dikeluarkannya Peraturan Menteri Pendidikan Nasional nomor 84 tahun 2008 tentang Pedoman PUG Bidang Pendidikan adalah moment penting untuk melaksanakan perubahan strategi pendidikan. Melalui penerapan peraturan menteri ini diharapkan setiap individu warga negara Indonesia laki-laki dan perempuan mempunyai kesetaraan baik dalam pelayanan pendidikan, berpartisipasi aktif, dan mempunyai kontrol serta mendapatkan manfaat pendidikan.

Perempuan dan ras minoritas dianggap menghadapi kerugian tertentu dalam pengaturan manajerial dan profesional. Gigih dan bahkan melebar ke arah kesenjangan pendapatan, tingkat promosi yang lebih lambat, dan kenaikan yang terpotong menunjukkan bahwa Glass Ceiling ada untuk perempuan dan ras minoritas. Istilah Glass Ceiling mengacu pada "penghalang buatan yang didasarkan pada sikap atau organisasi bias yang mencegah individu yang memenuhi syarat untuk maju ke atas dalam organisasi mereka ke posisi tingkat 
manajemen "(U.S. Department of Perburuhan 1991, 1).

Perkembangan karir wanita bisa tidak hanya tertinggal dari laki-laki tetapi mungkin lanjutkan dengan cara yang sama sekali berbeda (Larwood dan Gutek, 1987) dan sampai saat ini saja beberapa model karir mencoba untuk digabungkan berbagai pengalaman hidup wanita (Still dan Timms, 1998). Pada saat Peran pendidikan tinggi menjadi lebih penting dalam beberapa tahun terakhir ini pengusaha dan lapangan kerja menuntut angkatan kerja yang berpendidikan lebih baik untuk tetap kompetitif di ekonomi global yang berubah dengan cepat. Penelitian ini berfokus pada Glass Ceiling di dunia pendidikan.

Profesi guru tentu memiliki peran yang sangat strategis dalam penyelenggaraan pendidikan tentang gender di sekolah. Guru adalah pengambil kebijakan yang paling berpengaruh dan sentral dalam pendidikan (Datnow, 1998:9). Guru juga di anggap sebagai Perempuan yang dituntut menampilkan karakter feminim dan laki-laki berkarakter sebagai maskulin. Pekerjaan yang dipandang cocok untuk perempuan dan laki-laki pun berbeda biasanya perempuan di kondisikan mempunyai pekerjaan yang ringan sedangkan laki-laki cenderung kepada pekerjaan yang berat.

Sesuai dengan ciri-ciri itu, menjadi guru dipandang sebagaian orang cocok bagi perempuan, terutama untuk pendidikan jenjang rendah. Meskipun demikian, tidak banyak perempuan yang menjadi kepala sekolah sebagian hanya mampu menduduki jabatan sebagai guru saja. Sebagaimana jumlah guru, jumlah kepala sekolah perempuan ini makin berkurang seiring dengan meningkatnya jenjang sekolah. Untuk menjadi seorang kepala sekolah, guru terlebih dahulu harus mengikuti diklat calon kepala sekolah dan memiliki sertifikat LP2KS. Dalam permendiknas dijelaskan secara ekspilsit tentang seorang guru yang telah dinyatakan lulus seleksi sebagai calon kepala sekolah wajib untukmengikuti pendidikan dan pelatihan sebagai salah satu upaya pemberian pengalaman pembelajaran teoritis maupun praktis yang bertujuan untuk menumbuh kembangkan pengetahuan, sikap dan keterampilan pada dimensi-dimensi kompetensi kepribadian.

\section{Glass Ceiling}

Metafora Glass Ceiling sering digunakan mendeskripsikan hambatan dan hambatan, yang transparan, yang mencegah wanita meraih promosi ke tingkat atas dalam sebuah organisasi (Burke, Ronald dan Vinnicombe, Susan. 2005). Dengan kata lain, Glass Ceiling adalah sebutan untuk benda halus dan penghalang transparan, tetapi sangat menghambat perempuan (atau minoritas) untuk berkembang atau naik dalam manajemen hierarki (Choi, Sungjo dan Park, Chun Oh. 2014). Begitu bahwa Glass Ceiling seringkali tidak terlihat, tetapi dapat dirasakan wanita. Bullard dan Wright (Bullard, Angela M. Dan Wright, Deil S. 1993) mencontohkan Glass Ceiling sebagai fenomena ketika karyawan perempuan mendapat kesempatan untuk menempati posisi tinggi dalam struktur organisasi, tetapi sering dibenturkan dengan alasan di luar kualifikasi. Secara khusus, Departemen Tenaga Kerja AS pada tahun 1991 (Hind, Patricia dan Baruch, Yehuda. 1997) mendefinisikan bahwa Glass Ceiling adalah pembatas buatan berdasarkan attitudinal atau bias organisasi, yang menghalangi individu yang memenuhi syarat untuk naik level di dalam organisasi mereka. Jadi berdasarkan 2 pendapat di atas maka, Glass Ceiling merupakan pembatas yang tidak terlihat dan artifisial.

Hambatan yang menghalangi perempuan untuk naik ke posisi manajemen senior di perusahaan besar telah sering digambarkan dengan metafora "GC", penghalang transparan yang mencegah wanita dari naik tangga perusahaan melewati titik tertentu. (Morrison, White, Van dan pusat Kepemimpinan Kreatif, 1987). Sesuai Weyer (2007) kelangkaan pemimpin perempuan terkait dengan prasangka dan diskriminasi yang berkelanjutan terhadap perempuan di tempat kerja. Ini mengacu meskipun wanita sekarang mampu naik ke level atas, pada titik tertentu mereka terhalang oleh penghalang tak terlihat. Ini berlaku untuk wanita sebagai kelompok yang dihalangi untuk maju karena mereka adalah wanita (Morrison et al., 1987).

Sebagian besar wanita merasa bahwa sementara rekan pria mereka tidak memiliki tanggung jawab untuk itu pekerjaan rumah tangga dan pengasuhan anak selama kehidupan kerja mereka, mereka secara pribadi terus mengemban tanggung jawab ini dan bahwa tanggung jawab ini meningkatkan tingkat stres 
mereka, struktur keluarga memiliki berdampak besar pada kesuksesan karir (Schneer dan Reitman, 2002)

\section{Pengembangan Karir Wanita}

Pengembangan karir secara tradisional dikonseptualisasikan dalam konteks yang lebih luas, memerlukan urutan yang berurutan dan sistematis sikap dan perilaku yang terkait dengan pengalaman terkait pekerjaan, yang mengakui kehidupan pribadi individu selama seluruh rentang siklus hidup (White etal., 1992). Pengembangan karir dapat jelaskan sebagai serangkaian aktifitas yang mengarah pada penilaian dan penguatan karir bagi seseorang baik itu pria atau wanita, untuk memfasilitasi pencapaian tujuan karir di masa depan. Konsep lain yang berhubungan dengan karir untuk memfasilitasi pencapaian tujuan karir adalah jalur karir. Jalur karir adalah jalur yang seseorang ambil untuk mencapai tujuan karir. Melalui jalur karir, seorang karyawan dapat mengikuti instruksi untuk mengimplementasikan pengembangan karir.

Menurut Thomas dan Pullen (2000, p. 1) berpendapat bahwa penelitian yang sudah ada berkaitan dengan organisasi dan manajemen hampir secara eksklusif dari bidang gendernetral posisi tetapi tunjukkan bahwa kritik ini kurangnya kesadaran gender bukanlah hal baru. Teori manajemen, Hearn (1994, p.195) berpendapat, cenderung mengabaikan isu gender sepanjang abad kedua puluh. Dia berkomentar bahwa sungguh menakjubkan bagaimana pria bisa dominasi pengurus belum menjadi sebuah topik serius yang menjadi perhatian dalam manajemen teori dan pemikiran manajemen.

Dikatakan bahwa beberapa pendapat tentan korpokratis tradisional model pengembangan karir sebagian besar telah premissed pada pengalaman kerja laki-laki, berdasarkan nilai dan tujuan. Hasil dari penelitian di dapati adalah banyak dari apa yang kita ketahui tentang tahapan-tahapan yang dilalui seseorang, saat dia bersiap untuk menemukan tempatnya di dunia kerja, mungkin secara tepat diberi label " kejuruan perkembangan laki-laki kelas menengah " (Tyler, 1977).

\section{METHOD}

Penelitian utama ditekankan oleh kerangka konseptual ini adalah, GC mempengaruhi WCD. GC mungkin mempengaruhi sebagai variabel independen. WCD adalah variabel dependen. Oleh karena itu kehidupan karir wanita tergantung pada beberapa variabel independen. Faktor Budaya (FB), Faktor Individu (FI), Faktor Organisasi (FO) dan Faktor Keluarga (FP) dipertimbangkan sebagai variabel independen dalam kerangka ini.

\section{Variabel bebas}

Pengukuran GC didasarkan pada empat dimensi dan dimensi tersebut adalah FI,FK,FO,FB.

- Faktor Individu - Kriteria ini mencerminkan sejauh apa penghalang seseorang yang datang dari diri mereka sendiri dapar mempengaruhi hasil.

- Faktor Keluarga - Kriteria ini adalah sejauh mana penyebab hubungan mempengaruhi kinerja karyawan.

- Faktor Organisasi - Ini mencerminkan sejauh mana karyawan melihat organisasi sebagai tanggung jawab atas kurangnya kinerja karyawan atau sejauh mana organisasi hambatan yang berasal dari struktur organisasi dan praktik mempengaruhi karyawan pengembangan.

- Faktor Budaya - Ini mengacu pada seberapa jauh kepercayaan serta tradisi mampu mempengaruhi pengembangan karyawan.

\section{Variabel Terikat}

Pengukuran untuk variabel tidak bebas didasarkan pada tiga komponen oleh Afza dan Newaz (2008). Itu Berfokus pada Karir, Dukungan Keluarga dan Sikap terhadap Organisasi.

- Karir mengacu pada karyawan yang tertarik untuk memajukan atau mencapai karir mereka. Orang-orang dengan upaya fokus karir yang tinggi untuk mengembangkan profesinya.

- Keluarga- Dukungan keluarga mencerminkan, dukungan yang diberikan oleh anggota keluarga untuk terus berlanjut kesuksesan profesi seseorang. Orang yang 
memiliki dukungan keluarga yang baik atau tinggi mencapai situasi menyeimbangkan kehidupan kerja-keluarga dan mengembangkan profesinya.

- Sikap Terhadap Organisasi- Sikap terhadap Organisasi mengacu pada pendapat karyawan dalam hal organisasi kerja. Orang dengan sikap positif tentang organisasi bekerja tetap dengan asal dan mengembangkan karir mereka di dalamnya

INDIPENDENT VARIABEL

DEPENDENT VARIABEL organisasi dan konflik kehidupan kerja merupakan faktor kedua yang paling signifikan.

\section{RESULTS AND DISCUSSION}

Pada penelitian ini, jumlah responden adalah sebanyak 110 guru. jumlah responden yang berusia diatas 35 tahun menjadi dominan responden yaitu 32\%. Persentase responden berikutnya $29 \%$ yaitu usia 26 sampai 30 tahun, dilanjutkan $26,3 \%$ yang ada pada rentang usia 31-35 tahun. Dan usia guru perempuan 21 sampai 25 dan dibawah 21 tahun yaitu $10 \%$ dan $2,7 \%$.

Deskripsi Responden

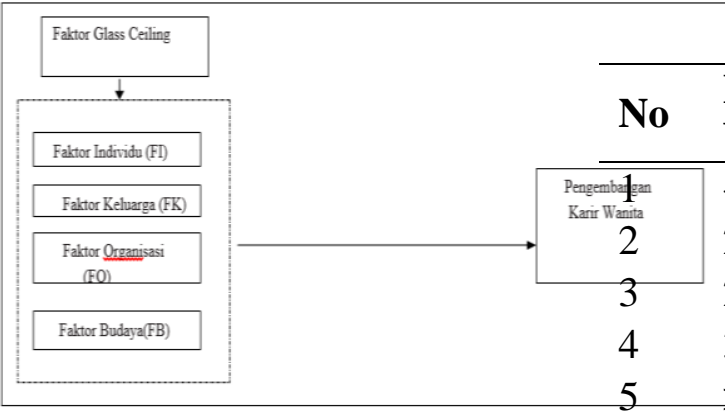

Studi penelitian ini mengandalkan metod survei untuk pengumpulan data; survei berbasis kuesioner tentunya sudah lazim digunakan dalam penelitian. Kuesioner yang diberikan sendiri dikembangkan sebagai instrumen survei. Populasi dalam penelitian ini adalah guru wanita yang bekerja di sektor pendidikan swasta di kota Pekanbaru. Teknik clustered dan simple random sampling digunakan untuk memilih sampel penelitian. sebanyak 110 guru dan dijadikan sampel untuk penelitian ini.

Maheshwari (2012) menunjukkan bahwa hambatan global GC dapat secara luas dibagi menjadi tiga kategori yaitu, hambatan terkait individu, sosial dan organisasi. Menurut Williams dan Cooper (2004), "perempuan melakukan 65-85 persen pekerjaan perawatan anak dan lebih dari 70 persen pekerjaan perawatan lansia". Afza dan Newaz (2008) telah mengajukan lima faktor utama yang mempengaruhi efek GC dalam organisasi: Persepsi Manajemen, Lingkungan kerja, Konflik kehidupan kerja, Pelecehan seksual, Kebijakan Organisasi. Studi menunjukkan bahwa persepsi manajemen dan lingkungan kerja merupakan faktor yang paling signifikan untuk menciptakan GC dimana kebijakan

\section{Deskripsi Variabel Glass Ceiling}

Glass Ceiling merupakan faktor yang mempengaruhi proses pengembangan karir perempuan. Variebel Glass Ceiling termuat dalam 16 item pernyataan kuesioner. Berikut ini skor rata-rata variabel Glass Ceiling berdasarkan data yang diperoleh dari kuesiner penelitian, dapat dilihat pada tabel dibawah ini:

Kecenderungan Skor Rata-Rata Variabel Glass Ceiling (X)

\begin{tabular}{|c|c|c|c|}
\hline No & Indicator & Mean & Kategori \\
\hline 1 & $\begin{array}{lr}\text { Saya } & \text { mendapati } \\
\text { kesulitan } & \text { dalam } \\
\text { mengubah } & \text { antara } \\
\text { peran keluarga dan } \\
\text { pekerjaan }\end{array}$ & 4,05 & Tinggi \\
\hline 2 & $\begin{array}{l}\text { Saya merasa bersalah } \\
\text { karena tidak cukup } \\
\text { banyak waktu lagi } \\
\text { untuk urusan keluarga }\end{array}$ & 4,01 & Tinggi \\
\hline 3 & $\begin{array}{l}\text { Saya telah } \\
\text { mengorbankan hal lain } \\
\text { ( misalnya sosial, } \\
\text { kehidupan keluarga) di } \\
\text { dalam kemajuan karir }\end{array}$ & 3,21 & Tinggi \\
\hline 4 & $\begin{array}{l}\text { Saya mempunyai } \\
\text { akses pada jaringan }\end{array}$ & 3,39 & Tinggi \\
\hline
\end{tabular}


pemerintah

5 Saya mempunyai

akses pada jaringan

3,36 Tinggi

bisnis

( jaringan formal untuk

membangun kontak

bisnis)

6 Saya mempunyai

akses jaringan

profesional

7 Saya mempunyai

akses jaringan sosial

(informal)

8 keluarga

mendukung profesi

saya

9 Keluarga

menyemangati

saya

memotivasi

dan

saya

dalam ketika muncul

permasalahan di dalam

pekerjaan saya

10 Anggota keluarga saya

bekerjasama dalam

urusan internal di

rumah

11 Keluarga saya pada umumnya bangga akan pekerjaan dan prestasi saya

12 Saya sukses di tempat kerja adalah kerana memiliki keluarga yang tentram

13 Saya mempunyai seseorang yang dapat diajakberbicara ketika memerlukan nasehat

14 Saya memiliki keyakinan yang kuat ketika bekerja dan ada seseorang yang membimbing saya

15 Saya mempunyai seseorang yang mengizinkan saya meraih peluang sebagai bentuk pembuktian

kemampuan dan bakat saya mempunyai

3,78 Tinggi

3,76 Tinggi

3,44 Tinggi

4,30 Sangat

Tinggi

3,51 Tinggi

3,58 Tinggi

3,75 Tinggi

3,62 Tinggi

3,88 Tinggi

3,87 Tinggi orang yang mampy

memberikan petunjuk

yang lebih baik untuk

saya agar tercapai

keseimbangan antara

pekerjaan saya dan

komitmen pribadi saya

Rata-rata variabel

Glass Ceiling

Sumber : Data Kuesioner

Berdasarkan pengolahan data, secara keseluruhan rata-rata skor untuk variabel Glass Ceiling adalah 3,75 . Hal ini menunjuk bahwa Glass Ceiling pada guru di Kota Pekanbaru berada pada kategori tinggi. Semakin tinggi kondisi Glass Ceiling akan membawa dampak pada praktek gender dalam proses pengembangan karir.

Berdasarkan gambar diperoleh gambaran bahwa skor rata-rata untuk masing-masing indikator belum mencapai skor maksimal idel $(5,00)$. Walaupun demikian, secara empirik menunjukkan praktek gender dalam dapat dijadikan acuan untuk mengukur Glass Ceiling. Hal ini menunjang kegiatan praktek yang akan membantu dalam pencapaian pengembangan karir.

\section{Hipotesis Secara Parsial (uji t)}

Uji hipotesis secara parsial dengan menggunakan uji t disajikan pada tabel berikut:

\begin{tabular}{|c|c|c|c|c|c|}
\hline \multicolumn{6}{|c|}{ Uji Hipotesis Secara Parsial (Uji t) } \\
\hline $\begin{array}{l}\text { Variab } \\
\text { el }\end{array}$ & $\begin{array}{l}\mathrm{t} \\
\text { hitung }\end{array}$ & & $\mathrm{t}_{\text {tabel }}$ & $\begin{array}{l}\text { Keputus } \\
\text { an }\end{array}$ & $\begin{array}{l}\text { Kesimpul } \\
\text { an }\end{array}$ \\
\hline $\mathrm{X}$ & $\begin{array}{l}1,02 \\
6\end{array}$ & $<$ & $\begin{array}{l}1.65 \\
9\end{array}$ & $\begin{array}{l}\mathrm{H}_{0} \\
\text { diterima } \\
\mathrm{Ha} \\
\text { ditolak }\end{array}$ & $\begin{array}{l}\text { Tidak } \\
\text { Signifika } \\
\mathrm{n}\end{array}$ \\
\hline
\end{tabular}

Dalam pengujian hipotesis melalui uji t ini, penulis menggunakan tingkat kepercayaan $95 \%$, $\alpha=0,05$. Adapun uji t masing-masing variabel bebas Glass Ceiling adalah sebagai berikut:

Uji t Pengaruh Glass Ceiling Terhadap pengembangan karir

Dari tabel di atas uji t dengan menggunakan SPSS 24 untuk koefisien (Glass Ceiling) di peroleh t hitung sebesar 1,026, kemudian t tabel dengan derajat kepercayaan $95 \%$ diperoleh nilai 1.659 data menunjukan bahwa t hitung $<\mathrm{t}$ tabel atau 1,026<1.659 berada pada daerah Ho diterima, artinya hipotesis di dalam penelitian 
ini Ho diterima dan Ha ditolak maka Glass Ceiling tidak berpengaruh terhadap pengembangan karir.

Tujuan utama dari penelitian ini adalah untuk mengetahui pengaruh Glass Ceiling pada pengembangan karir wanita pada guru di Sekolah Menengah Atas di kota Pekanbaru secara keseluruhan, penelitian ini menunjukkan bahwa Glass Ceiling memiliki pengaruh 3,5\% terhadap Pengembangan Karir pada Guru Sekolah Menengah Atas Pekanbaru.

Hasil temuan ini tidak mendukung hasil temuan penelitian sebelumnya seperti penelitian yang di sebutkan oleh $\mathrm{O}$ 'Brien(O'Brien, Denise $\mathrm{H}$. 2013), yang menyatakan bahwa wanita cenderung mengalami keraguan dan ketidakpastian dalam karirnya yang mereka sebut Glass Ceiling hal ini tentu berbanding terbalik dengan hasil penelitian ini.

\section{CONCLUSIONS}

Tujuan dari penelitian ini adalah menganalisis pengaruh fenomena Glass Ceiling menghambat pengembangan karir perempuan dalam mengembangkan karir mereka. Penelitian ini Menggunakan metode grounded theory, langkah pertama ini (pengkodean terbuka) menghasilkan ada empat kategori indikator dari Glass yaitu perseorangan (pribadi) interpersonal, keluarga, organisasi dan budaya. Penelitian ini telah mengidentifikasi beberapa faktor yang bertanggung jawab untuk menciptakan efek Glass Ceiling.

Berdasarkan hasil penelitian diantara faktor Glass Ceiling yang paling berpengaruh adalah faktor organisasi. Oleh karena itu, para pekerja laki-laki harus bekerja untuk menghindari hambatan individu seperti kurangnya rasa percaya diri, terlalu emosional dalam pekerjaan pekerja dengan mengembangkan rasa percaya diri dan berpikir positif karena bangunan tersebut dapat melakukan persepsi..

Banyak penelitian yang menunjukkan fenomena Glass Ceiling terjadi baik di organisasi swasta maupun organisasi publik. Dalam konteks organisasi publik, meskipun partisipasi perempuan dalam angkatan kerja meningkat dan kesempatan untuk menduduki posisi tinggi terbuka untuk perempuan, tetapi Fakta membuktikan bahwa prestasi karir wanita sangat jarang menduduki level yang tinggi. Hasil dari riset ini sesuai dengan penelitian yang dilakukan oleh Murniati (Murniati, Caecilia Titiek. 2012) yang menyimpulkan bahwa indikator keluarga adalah kunci bagi perempuan di upaya untuk mengelola tekanan antara pekerjaan dan peran domestik (peran dalam keluarga).

\section{REFERENCES}

Afza, S., \& Newaz, M. (2008). Factors determining the presence of $\mathrm{GC}$ and influencing

women career advancement in bangladesh. Bbrac University Journal, 5(1), 85-92.

Burke, Ronald and Vinnicombe, Susan 2005. Advancing women's careers. Career Development International. Vol, 10 No. 3, pp. $165-167$.

Choi, Sungjo and Park, Chun Oh. 2014. Glass Ceiling in Korean civil service: analyzing barriers to women's career advancement in the Korean government. Public Personnel Management, Vol. 43 No. 1, pp. 118-139.

Choi, Yujin. 2015. Career success factors of women in the public sector: an empirical analysis of the Korean central government. Asian Social Science, Vol. 11 No. 9, pp. 300311.

Cornelius, Nelarine and Skinner, Denise. (2005). An alternative view through the glass ceiling, using capabilities theory to reflect on the career journey of senior women. Women in Management Review, Vol. 20 No. 7/8, pp. 595 $-609$

Cooper, D. R., \& Schindelr, P. S. (2001). Business research methods. Sydney: McGrawHill.

Datnow, Amanda, 1998. The Gender Politics of Educational Change. London: Falmer Press

Hearn, J. (1994), “'Changing men and changing managements: social change, social research and social action", in Davidson, M. and Burke, R.J. (Eds), Women in Management: Current Research Issues, Paul Chapman, London, Ch. 13. 
Larwood, L. and Gatticker, U.E. (1987), “A comparison of the career paths used by the successful men and women", in Gutek, B.A. and Larwood, L. (Eds), Women's Career Development, Sage, Newbury Park, CA.

Larwood, L. and Gutek, B.A. (1987), “'Working towards a theory of women's career development", in Gutek, B.A., Stromburg, A.H. and Larwood, L. (Eds), Women and Work: An Annual Review, Sage, Newbury Park, CA.

Morrison, A. M., White, R. P., Velsor, E., \& The Center for Creative Leadership (1987).

Breaking the GC: Can women reach the top of America's largest corporations? Reading, MA: Addison- Wesley.

Murniati, Caecilia Titiek. 2012. Career advancement of women senior academic administrators in Indonesia: Support and Challenge. Dissertation, Graduate College, The University of Iowa, Iowa City, Iowa, retrieved from Proquest

O'Brien, Denise H. 2013. Women in Public Sector Who Experience Feelings of Bumping their Heads on the Glass ceiling: A Grounded Theory Study. a Dissertation of Capella University, retrieved from Proquest.

Scandura, T. (1992). Breaking the GC in the 1990s. Washington, DC: U.S. Department of Labor Women's Bureau.
Schneer, J., \& Reitman, F. (2002). Managerial life without a wife: Family structure and

managerial career success. Journal of Business Ethics, 37(1), 25-38. http://dx.doi.org/10.1023/ A: 1014773917084

Thomas, R. and Pullen, A. (2000), 'What do you want from me? A gendere analysis of middle managers' identities", paper presented at the British Academy of Management Conference, University of Edinburgh, Edinburgh, 13-15 September.

White, B. (1995), “The career development of successful women", Women in Management Review, Vol. 10 No. 3, pp. 4-15.

Tyler, C. (1977), “The encounter with poverty its effects on vocational psychology", in Peters, H.J. and Hanson, J.C. (Eds), Vocational Guidance and Career Level, 3rd ed., Macmillan, New York, NY.

White, B., Cox, C. and Cooper, C.L. (1992), Women's Career Development: A Study of High Flyers, Blackwell Business, Oxford. 